\title{
活断層情報を考慮した防災対策と住民の意識構造
}

\author{
照 本 清 峰* 中 林一 樹**
}

\section{A Study on the Perception of Earthquake Risk and Disaster Reduction Measures Based on Active Fault Information}

Kiyomine TERUMOTO* and Itsuki NAKABAYASHI**

\begin{abstract}
Active fault information has been more widely and closely researched, and extensive data have been collected. With the progress, earthquake disaster reduction measures based on active fault information should be examined. The purpose of this paper is to arrange disaster reduction measure cases that have been considered with active fault information, and to indicate problems and directions to promote disaster reduction measures based on a questionnaire survey. Disaster reduction measures based on active fault information are distinguished into three types: building restrictions, non-building restrictions, and risk communication. The questionnaire survey was carried out with residents of Yokosuka city. The questionnaire items concerned the recognition and perception of regional earthquake risk, the perception of general earthquake risk, the awareness of general disaster reduction measures, and the awareness of disaster reduction measures based on active fault information. The results show that there are also three factors in the perceptions of residents, which are building restrictions, non-building restrictions, and risk communication, and their measures may be implemented with the recognition of residents on the need for land use controls based on active fault information. Other analysis results indicate that earthquake risk perception is high, but there are no significant correlations between individual earthquake risk perceptions and the awareness of disaster reduction measures. To promote disaster reduction measures based on active fault information and earthquake risk, it is important that such awareness is connected.
\end{abstract}

Key words : active fault, disaster reduction measures, building restrictions, questionnaire survey, Yokosuka city, risk perception, risk communication

キーワード：活断層，防災対策，建築規制，社会調査，横須賀市，住民意識，リスクコミュニケー ション

\section{I.はじめに}

兵庫県南部地震以降, 鳥取県西部地震, 新潟県 中越地震, 福岡県西方沖地震等, 被害をもたらす
多くの地震が発生しており，日本列島は地震活動 期に入ったといわれる。南海トラフ沿いを震源と する東海・東南海・南海地震, 宮城県沖地震, 首 都圈直下地震等の発生も切迫性を増していると考

* (財) ひょうご震災記念 21 世紀研究機構 人と防災未来センター

** 首都大学東京大学院都市環境科学研究科

* The Great Hanshin-Awaji Earthquake Memorial Disaster Reduction and Human Renovation Institution

** Graduate School of Urban Environmental Sciences, Tokyo Metropolitan University 
えられ, 地震防災対策を推進していくことは重要 な課題となっている。一方で地震被害のもとにな る活断層の調査は, 特に兵庫県南部地震以降, 地 震調査研究推進本部を中心として多く取り組まれ ており，活断層情報の精度は向上するとともに デー夕も蓄積されてきている。このような中, 活 断層情報の防災対策への活用を検討することも求 められる。

中田（1996）は，都市計画に活断層情報を考 慮した事例がほとんどないことを指摘するととも に，「活断層法」の制定を主張している。村山・ 増田（2001）は，活断層情報が防災対策に活か されていないことを示すとともに，活断層情報を 考慮した防災対策の導入可能性を検討している。 また中田・隈元（2003）は, 全国の活断層と学 校施設の位置関係から多くの学校施設が活断層の 近傍にあることを分析し, 多数の学生が危険性の 高い空間で多くの時間を過ごすことになる問題を 指摘している。地震リスクの受容範囲の観点か ら, 活断層周辺地域において公共施設, 危険施設 等の特定の構造物については規制に関する検討が 必要であるという指摘もある(照本, 2004)。さ らに照本（2007）は，活断層情報を考慮した対 策の考え方を地震リスクの観点から検討してい る。

鈴木（2001）は，活断層地震対策については 安全性の向上と費用との兼ね合いの程度問題であ ることを指摘した上で, 活断層対策の実行可能性 については今後の世論次第であることを述べてい る。自治体職員と地域住民に対する意識調査か ら，危険地域に対する建築制限については賛成の 傾向にあることが示されている（増田・村山， 1998)。活断層の近くでの建築規制に対しては賛 成意見が多いという同様の結果を示した市民対象 の調査結果もある（読売新聞朝刊〔大阪本社発行 版了, 2006)。さらに, 地震調査研究推進本部政策 委員会成果を社会に活かす部会 (2001)によって, 研究者, 報道機関関係者等も活断層情報を考慮し て何らかの規制をすることに肯定的な傾向にある ことが示されている。

一方で損害保険料率算定会（2000）は，研究
者を対象とした調査から，活断層周辺の建築規制 については「必要だが現実的ではない」という意 見の多いことを示している。また活断層の地震発 生確率が低い場合には住民に問題として見られな い可能性があるとともに, 地震発生確率の高さの 違いによって対策の需要程度に違いのあることも 指摘されている（照本・望月, 2001）。

活断層情報を考慮した防災対策を検討するため には，都市・地域計画的手法について検討すると ともに，住民の意識を考慮して対策を検討するこ とも同時に求められる。そこで本研究では, (1)活 断層情報を考慮した防災対策事例を通じて，対策 の分類・整理をするとともに，(2)地域住民を対象 とした意識調査をもとに住民の意識構造を分析 し，活断層情報を考慮して防災対策を推進させる ための課題と対策の方向性を示すことを目的とす る。

防災対策を推進していくためにはリスクコミュ ニケーションが必要だといわれる1)。しかしなが らそれではどのようにリスクコミュニケーション を行っていけば効果的に対策を推進できるか, と いう点についての研究と実践はまだ途上段階にあ る。本研究では, 防災対策の実現につなげていく ためのリスクコミュニケーションの課題は何か, という点について検討する。

\section{II. 活断層情報を考慮した土地利用の 事例と対策の考え方}

ここでは，活断層情報を考慮した国内外の防災 対策事例を概観し，事例をもとに防災対策の方法 を整理する。

\section{1）活断層情報を考慮した国内の対策事例}

活断層情報を考慮して具体的に防災対策に取り 組んでいる我が国の事例として，条例に基づいて 活断層線周辺地域の建築指導を行う事例, 活断層 周辺地域において地区計画制度に基づく土地利用 規制を行っている事例がある。

兵庫県西宮市では, 阪神・淡路大震災を契機と して「震災に強いまちづくり条例」を 1995 年に 施行している2)。条例により，市街化区域内の対 象となる活断層周辺区域におけるマンションや宅 
地造成等の新規開発時には，市から活断層情報を 提供するとともに，活断層を考慮するよう指導で きるようにしている。条例は物理的な規制策では ないが，情報提供等によって建築主の防災への配 慮を促すための制度である。

神奈川県横須賀市では, 新規開発事業地区で あった野比 $4 丁$ 目地区において, 地区計画制度 をもとに北武断層の両側 $25 \mathrm{~m}$ の範囲で建築を規 制している3)。規制は地区計画制度による建物の 壁面線の制限によって行われている。これによっ て，新規開発地区において総延長約 $400 \mathrm{~m}$ にわ たって北武断層を挟む両側 $25 \mathrm{~m}$ の範囲が建築禁 止になっている（図 1)。

\section{2）活断層情報を考慮した国外の対策事例}

活断層周辺地域において防災対策を実施してい る事例は世界的に幾つかある4。 アメリカ・カリ

フォルニア州では, サンフェルナンド地震 (1971 年）において特に断層沿いで被害が大きかったこ とを契機として，1972 年に Alquist-Priolo Special Studies Zoning Act（1993 年 Alquist-Priolo Earthquake Fault Zoning Act に改正, 以下, 活断 層法）が成立した ${ }^{5)}$ 。活断層法では，活断層を取 り囲む「地震断層地帯 (earthquake fault zones)」 を設定し ${ }^{6)}$ ，地震断層地帯内においては基本的に 人が居住する建築物の建築行為を禁止することを 定めている。地震断層地帯は, 州の地質官によっ て認定された断層線から両側 50 feet（約 $15 \mathrm{~m}$ ) の区域である。また「地震断層地帯」内において は，土地の売買等において情報を公開しなければ ならないことも定めている7)。カリフォルニア州 にはサンアンドレアス断層など多くの活断層が存 在し, 地震に対する危険性は高い。そのため, と くに活断層周辺地域の地表変位による建物被害の 軽減を目的として法律が定められている。

ニュージーランドでは, 既成市街地の活断層周 辺地域において建物の高さ制限を実施する事例, 住宅地の新規開発時において断層線を避けて開発 した事例等がある（馬場, 2003; 馬場ほか, 2004）。 これらは Resource Management Actに基づいて 実施されている。Resource Management Act で は, 建築用地のリスクの高低と建物の重要度に応

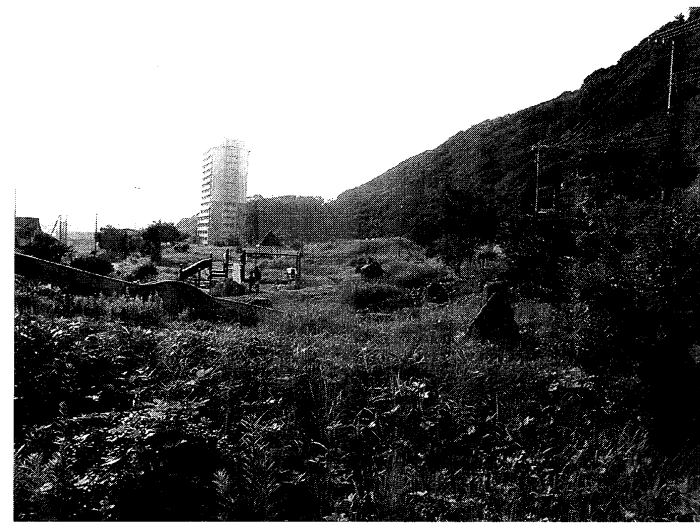

図 1 横須賀市野比 4 丁目地区の規制区域の様子. 規制の対象区域は公園, 駐車場等として利用 されている。横須賀市野比 4 丁目地区に扔いて 2006 年 9 月に筆者撮影.

Fig. 1 Building restriction area in Yokosuka city.

じて開発基準を設定するとともに, Resource consentによって自治体と開発行為者間で建築に 関して協議できるようにしている8)。ハザード情 報の収集・公開も積極的に行われている。

また台湾では, 921 集集地震後, 震源断層であ る車籠埔断層の地表断層線に沿って両側 $15 \mathrm{~m} の$ 範囲を建築制限する方策をとっている。921 集集 地震では断層線に沿って特に被害が甚大であった ため, 台湾政府は活断層近傍での被害の重大性を 認識し，建築制限を行うことを決定した（照本 · 王, 2001)。車籠埔断層の断層線に沿って長さ $105 \mathrm{~km}$ にわたって地表に変位が生じたため, 広 範囲な区域で帯状の建築制限が行われている（図 2)。また少数ではあるが建築制限区域において, 住民と行政協議によって面的整備事業が実施され ている事例もある（照本ほか, 2005）。

\section{3) 対策の枠組みの検討}

上記の事例をもとに対策の枠組みを整理する と, (1)建築構造物を物理的に規制する方法, (2)建 築を物理的に規制するのではなく活断層情報の提 供を義務づけることにより情報を有効活用する方 法, (3)住民との協議を通じて対策を検討するリス クコミュニケーションによる方法に分類すること ができる。以下，具体的に述べていく。 


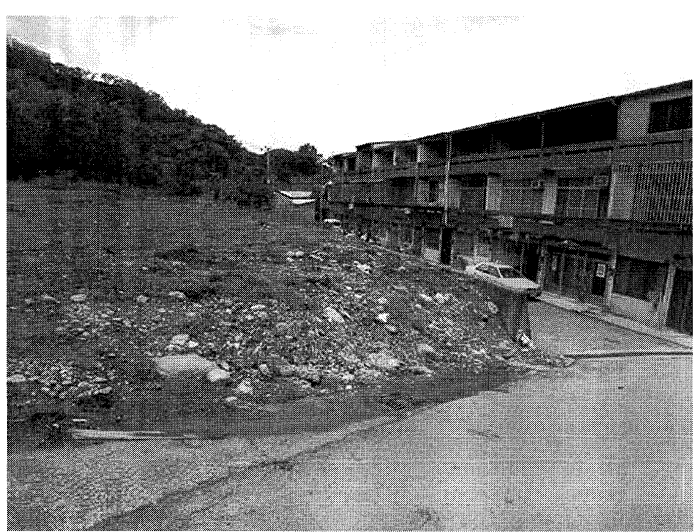

図 2 台湾台中県豊原市の活断層周辺地域の様子 写真の左側は断層の上盤側であり, 空地には 921 集集地震前には建物が建っていた。段差は 921 集集地震後に生じた。台中県豊原市活断層沿線 の規制区域において 2005 年 7 月に筆者撮影.

Fig. 2 Building restriction area in Fengyuan city, Taiwan.

第一に，活断層周辺地域の防災性能を高める方 法として, 構造物に対して建築制限をかける方法 が考えられる。仮に構造物を建設しなければ，そ の地区の地震リスクはなくなることになる。例え ば横須賀市の事例はこれに該当する。また活断層 周辺地域において全ての構造物の建設を禁止する のではなく，用途や構造等に対して一定の制限を 設ける対策もある。ニュージーランドや台湾で実 施されている建築制限はこれに該当することにな る。

第二に，建築の物理的な規制ではなく，活断層 情報の提供を義務づけることによって個々人の判 断を行えるようにするソフト的な方法が考えられ る。例えば，西宮市で行われている事例のよう に，中高層の建築物等を建設するときに活断層沿 いの建築を避けるように対策を促していく方法, また活断層の存在する区域においては詳細な地質 調査をあらかじめ実施する方法等, 新規建設時に おいて活断層情報を考慮する方法である。またカ リフォルニア州で実施されているように, 不動産 取引時において売り手が買い手に対して危険性の ある土地であることを知らせることを義務づける ような対策も考えられる。
第三に, 直接的に何らかの義務づけや制限をか けない方法が考えられる。活断層情報をもとに， 住民と行政機関が協議して対策を検討するという 方法である。そのためには, 活断層情報等のハ ザード情報を専門機関や行政機関から提供するこ とも条件になる。計画の検討結果によっては活断 層情報を考慮した面的整備事業に結びついていく 可能性もある。台湾で実施された対策は，住民の 活動等によって活断層沿いの建築用地を公園にす る等の空間整備がなされた事例である。

\section{III. 活断層情報を考慮した防災対策に 関する住民の意識}

前章においては活断層情報に基づく対策につい て検討してきた。活断層情報をもとに具体的に対 策の実行可能性とその方法を検討するためには, 住民の意識や意向を把握しておくことが重要であ る。ここでは, 前章の検討結果を踏まえ, 活断層 と地震防災対策に関する横須賀市住民を対象とし た意識調查をもとに，活断層情報を考慮した防災 対策に関する住民の意識構造を分析し，活断層対 策を中心とした防災対策の課題と対策を考察す る。

調查対象地域である横須賀市は首都圈に位置 し，市内には三浦半島断層群が存在する（神奈川 県, 2001)。地震調查研究推進本部は, 横須賀市 を通過する武山断層帯，衣笠・北武断層帯を社会 的・経済的に影響の大きい活断層としており，活 断層による地震危険性の高い地域といえる た横須賀市は先述したように実際に活断層情報を 考慮した土地利用を行っている数少ない自治体の 1つでもある。これらの理由から，活断層を中心 とした防災対策に関して相対的に意識の高い自治 体だと考えられるため，横須賀市において調査を 行った。

\section{1）調査の概要}

調査は横須賀市の 20 歳以上（2006 年 10 月時 点）の住民を対象とし，層下二段無作為抽出法に より住民基本台帳から 1500 名を抽出した。調査 方法は郵送配布・郵送回収による質問紙調査であ る。また調査においては，質問票のほかに，「活 
断層」,「首都圈直下地震」,「横須賀市を通過する 主な活断層である武山断層, 衣笠・北武断層」, 「横須賀市で実施されている活断層対策」に関す る概要の情報も参考資料として同封した。質問票 は 2006 年 10 月 19 日に発送し, 11 月 8 日に回 収を打ち切った。有効回答率は $25.9 \%$ であった。

\section{2）分析内容}

本研究においては, 首都圈直下地震と地域の活 断層に関する認知度と危機感，一般的な地震リス クに対する危機意識, 地震防災対策・活断層対策 の必要性に関する意識とそれらの各意識間の関係 について分析する。これらの分析結果から，危機 感や防災対策需要の程度を把握するとともに, 防 災対策として取り組むべき課題を考察する。

\section{3）分析結果}

\section{3-1）地域の地震危険性の認知度}

はじめに，地域の地震危険性の認知度及びそれ らに対する危機感の集計結果を示す。首都圈直下 地震と武山断層, 衣笠・北武断層の認知度につい てそれぞれに質問した。また「知っていた」と答 えた回答者には，それぞれの項目に対する危機感 についても尋ねた。罒 3 に各設問項目に対する 回答の集計結果を示す。図 3 より, 首都圈直下 地震, 武山断層, 衣笠・北武断層の認知度をみる とそれぞれ 87.5\% (329/376), 76.2\% (288/378)， $59.9 \%$ （226/377）であり, 首都圈直下地震の認 知度がもっとも高いことがわかる。

次にそれぞれの地震危険性に関する危機感につ いてみていく。危機感については,「強く危機感 を感じている」から「全く感じていない」の 5 件 法で質問している。以下では，「強く危機感を感 じている」を 5 点,「全く感じていない」を 1 点 として順序尺度を便宜的に間隔尺度とみなして分 析した。首都圈直下地震と武山断層, 及び首都圈 直下地震と衣笠・北武断層のそれぞれの危機感に ついて項目間で $\mathrm{t}$ 検定を行った結果, 統計的に有 意な差がみられた（それぞれ $\mathrm{t}=4.63, \mathrm{p}<0.000$, 及び $\mathrm{t}=3.01, \mathrm{p}<0.000) 。 一$ 方で武山断層と衣 笠・北武断層の間では統計的に有意な差はみられ なかった $(\mathrm{t}=1.30, \mathrm{p}>0.05)$ 。危機感において も, 地域の活断層よりも首都圈直下地震の危険性
(A)

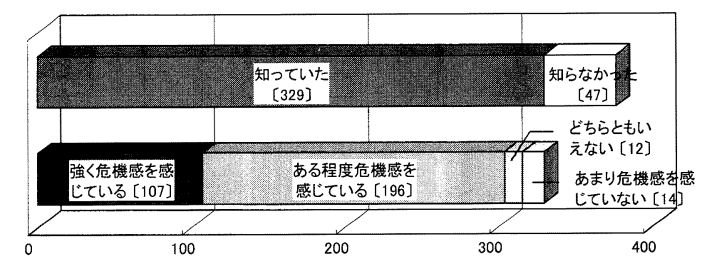

(B)

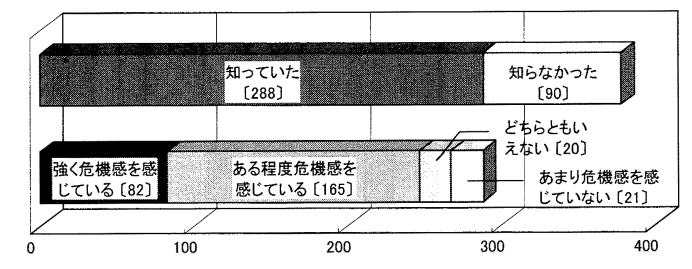

(C)

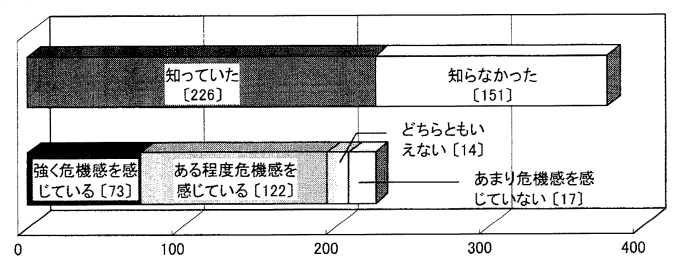

図 3 地域の地震危険性の認知度と危機感.

(A) 首都圈直下地震の認知度と危機感.

(B) 武山断層の認知度と危機感.

(C) 衣笠・北武断層の認知度と危機感.

Fig. 3 Recognition rates and earthquake risk perceptions of inhabited area.

(A) Recognition rate and risk perception of earthquakes beneath the metropolitan area.

(B) Recognition rate and risk perception of Takeyama fault.

(C) Recognition rate and risk perception of Kinugasa and Kitatake faults.

のほうが高く考えられている傾向にあった。

\section{3-2）地域の地震危険性に関する危機感と地震 リスクに対する危機意識の関係}

ここでは, 前節で示した地域の地震危険性に関 する危機感と一般的な地震リスクに対する意識の 関係を検討する。地震リスクに関する意識とし て, 地震に対する自宅建物の危機意識, 地震に遭 遇する危機意識, 延焼火災に関する危機意識を設 定している。

はじめに，地震リスクに対する意識に関する集 
(A)

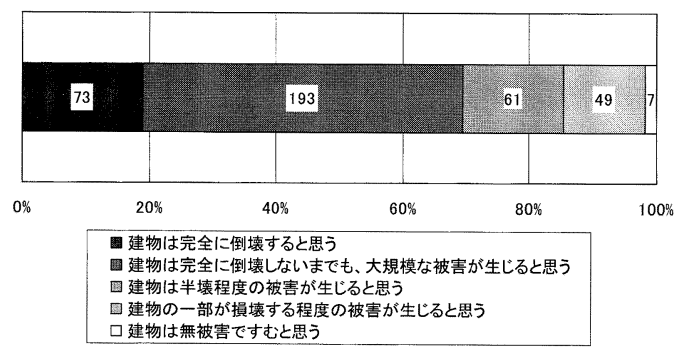

(B)

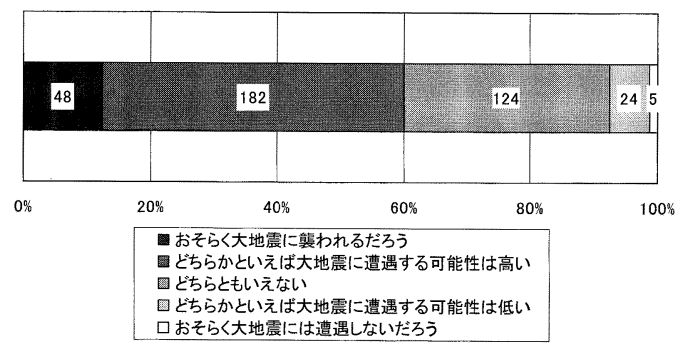

(C)

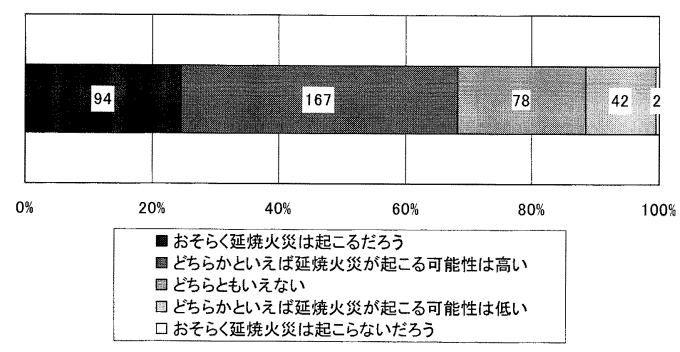

図 4 地震りスクに関する意識.

（A）自宅建物に関する危機意識.

（B）地震遭遇に関する危機意識。

（C）延焼火災に関する危機意識.

Fig. 4 Perceptions of earthquake risk.

(A) Perception of dwelling building risk.

(B) Perception of encountering risk of major earthquake.

(C) Perception of encountering fire spread risk.

計結果についてみていく。図 4 に自宅建物の危 機意識，地震遭遇の危機意識，延燒火災の危機意 識に対する各設問項目の回答の集計結果を示す。 自宅建物の危機意識については自宅が震度 7 程 度の地震による摇れに襲われたときの被害程度, 地震遭遇の危機意識は今後 30 年間で震度 7 程度
の摇れに襲われる可能性，延焼火災の危機意識に ついては大地震に襲われたときの自宅周辺の延焼 火災の危険性の程度について，それぞれ 5 件法 で尋ね, 図 4 に示した凡例のうちでもっともあ てはまる項目を1つ選択してもらった。図 4 よ り，いずれの項目とも回答結果にみられる危機意 識は高い傾向にあることがわかる。

次に地域の地震危険性に基づく危機感と地震り スクに関する意識の関係を把握するために，相関 分析を用いて検討する。地震リスクに対する各意 識項目については，例えば自宅建物の危険性なら 「建物は完全に倒壊すると思う」を 5 点,「建物 は無被害ですむと思う」を 1 点のようにして，各 意識項目ともに順序尺度を間隔尺度とみなして分 析した。表 1 に各項目間の分析結果を示す。

「首都圈直下地震に関する危機感」,「武山断層 に関する危機感」，「衣笠・北武断層に関する危機 感」間の相関関係についてみると, 当然ではある が「武山断層に関する危機感」と「衣笠・北武断 層に関する危機感」の関係を中心として強い傾向 にあることがわかる。地域の地震危険性の危機感 に対して地震遭遇危機意識，延焼火災危機意識は それぞれに弱い相関がみられる。一方で自宅建物 危機意識については，地域の地震危険性に関する 危機感のいずれの項目においても統計的に有意な 関係は認められなかった。地域の地震危険性と自 宅建物の危機意識の結びつきが弱いことを示す結 果であった。

\section{3-3）地震防災対策の重要性に関する意識}

ここでは，地震防災対策に関する意識について 確認しておく。地震防災対策に関する質問は，以 降で示す活断層周辺地域の防災対策に関する意識 との関連を検討するために設定した項目である。 地震防災対策に関する一般的な項目について, 各 設問項目とも「非常に重要である」から「まった く重要ではない」の 5 段階で尋ねられている。以 下では，「非常に重要である」を 5 点，「まった く重要ではない」を 1 点としてそれぞれを間隔 尺度とみなして集計・分析した。表 2 に各項目 の集計結果を示す。平均值はほほ同じ值である が,「行政機関の行う構造物に頼らない対策」に 
表 1 各意識項目間の相関分析結果.

Table 1 Results of correlation analysis.

\begin{tabular}{l|l|l|l|l|l|l}
\hline & \multicolumn{1}{|c|}{$(1)$} & (2) & (3) & (4) & (5) & (6) \\
\hline (1)首都圏直下地震危機感 & 1.00 & & & & & \\
\hline (2)武山断層危機感 & $0.56^{* *}$ & 1.00 & & & & \\
\hline (3)衣笠·北武断層危機感 & $0.52^{* *}$ & $0.90^{* *}$ & 1.00 & & & \\
\hline (4)自宅建物危機意識 & 0.10 & 0.06 & 0.10 & 1.00 & & \\
\hline (5)地震遭遇危機意識 & $0.37^{* *}$ & $0.28^{* *}$ & $0.30^{* *}$ & $0.10^{*}$ & 1.00 & \\
\hline (6)延焼火災危機意識 & $0.18^{* *}$ & $0.18^{* *}$ & $0.18^{* *}$ & $0.25^{* *}$ & $0.24^{* *}$ & 1.00 \\
\hline
\end{tabular}

表 2 地震防災対策の重要性に関する各意識項目の集計結果.

Table 2 Awareness of importance of disaster reduction measures.

\begin{tabular}{|c|c|c|}
\hline 項 & 平均 & 標準偏差 \\
\hline $\begin{array}{l}\text { 住民自らが, 自分や家族の生命・財産を守るた } \\
\text { めに行う地震防災対策 }\end{array}$ & 4.32 & 0.55 \\
\hline 地震被害の軽減のための基盤施設の整備・強化 & 4.29 & 0.67 \\
\hline $\begin{array}{l}\text { 地域の住民同士（自治会や町会, 自主防災組織 } \\
\text { など）で行う防災対策 }\end{array}$ & 4.17 & 0.63 \\
\hline $\begin{array}{l}\text { 地震被害の危険性を軽減させるための土地利用 } \\
\text { の推進 }\end{array}$ & 4.07 & 0.76 \\
\hline $\begin{array}{l}\text { 行政機関が行う, 緊急時の危機管理体制の整備 } \\
\text { などの構造物に頼らないソフト的な防災対策 }\end{array}$ & 3.94 & 0.77 \\
\hline
\end{tabular}

関する項目がもっとも低い結果であった。

\section{3-4）活断層周辺地域の防災対策に関する意識}

次に，活断層情報を考慮して実施する防災対策 についての意向についてみていく。前述において 検討した対策事例を参考にして，活断層情報を考 慮した防災対策に関する設問項目を設定した。質 問は，各設問項目に対して「非常に実施していく べき」から「まったく実施していくべきではない」 の 5 件法で尋ねた。また設問項目中にある活断 層周辺地域としてはおよそ活断層の断層線から両 側 $15 \mathrm{~m}$ 程度の範囲を目安としてもらうように設 問中に注釈をいれてある。以下では，「非常に実 施していくべき」を 5 点，「まったく実施してい くべきではない」を 1 点として順序尺度を間隔 尺度と見なして分析した。表 3 に各設問項目の
集計結果を示す。

11 項目中 9 項目で平均值は 4.0 以上であり, 活断層情報を考慮して防災対策を実施することに 関しては賛成の傾向にあるとみることができる （表 3)。その中で,「11耐震性能の低い建物に対 して罰則的な税金をかけること」の項目は，平均 值 3.11 と相対的に低い值であった。他の項目と 比較して，罰則的な対策を実施することについて は意向の強くないことがうかがえる。また，「10 活断層の周辺地域では, 構造物の建築を全て禁止 すること」の項目についても平均值は 3.64 であ り，相対的に低い值である。活断層周辺地域にお いて全面的に建築を禁止するよりも，用途・構造 など，何らかの制限を設けることによって対策を 実施していく意向のほうが高い結果であった。 
表 3 活断層情報を考慮した対策に関する各意識項目の集計結果.

Table 3 Awareness of disaster reduction measures based on active fault information.

\begin{tabular}{|c|c|c|}
\hline 項 & 平均 & 標準偏差 \\
\hline $\begin{array}{l}\text { (1)行政機関から活断層の位置や地震の危険性に関する情報を住民に } \\
\text { 対して提供すること }\end{array}$ & 4.51 & 0.62 \\
\hline (2)活断層の周辺区域にある石油タンク等の危険施設を撤去すること & 4.50 & 0.79 \\
\hline $\begin{array}{c}\text { (3)活断層に近い建物や土地を売買するときには, 活断層が近くにあ } \\
\text { るという情報を不動産取引時に提供することを義務づけること }\end{array}$ & 4.49 & 0.74 \\
\hline $\begin{array}{c}\text { (4)活断層の位置や危険性に関する情報をもとに, 住民と行政が話し } \\
\text { あって防災対策を検討すること }\end{array}$ & 4.38 & 0.65 \\
\hline $\begin{array}{l}\text { (5)中高層のマンションに対しては活断層の近くに建物を建てないよ } \\
\text { うに行政から業者を指導していくこと }\end{array}$ & 4.33 & 0.77 \\
\hline $\begin{array}{c}\text { (6)活断層の周辺区域で建物を建設する場合には, 法律で定められて } \\
\text { いる建築基準よりも安全性を高めるように建築を制限すること }\end{array}$ & 4.30 & 0.79 \\
\hline $\begin{array}{l}\text { (7)活断層の周辺地域では, 活断層の位置を確認するために地盤の調 } \\
\text { 查をして, 活断層をさけて建築するように義務づけること }\end{array}$ & 4.21 & 0.85 \\
\hline 8活断層の周辺地域では, 学校の建設を禁止すること & 4.15 & 0.98 \\
\hline $\begin{array}{l}\text { (9)活断層の周辺地域では, 病院・警察等の災害時に重要な役割を果 } \\
\text { たす公共施設の建設を禁止すること }\end{array}$ & 4.06 & 0.97 \\
\hline (10)活断層の周辺地域では, 構造物の建築を全て禁止すること & 3.64 & 0.93 \\
\hline $\begin{array}{l}\text { (11)活断層周辺地域で耐震性能の低い建物に対しては, 一定の罰則的 } \\
\text { な税金をかけること }\end{array}$ & 3.11 & 1.02 \\
\hline
\end{tabular}

表 4 因子分析結果.

Table 4 Result of factor analysis.

\begin{tabular}{l|rrr|c}
\hline \multicolumn{1}{c|}{ 項 } & \multicolumn{1}{c|}{ 目 } & F2 & F3 & 共通性 \\
\hline (8)学校建設禁止 & 0.964 & -0.052 & -0.040 & 0.824 \\
(9)災害時重要施設建設禁止 & 0.886 & -0.051 & -0.029 & 0.698 \\
(2)危険施設建設禁止 & 0.478 & 0.122 & 0.120 & 0.417 \\
(10)構造物建設禁止 & 0.454 & 0.313 & 0.033 & 0.543 \\
(7)活断層調查義務づけ & 0.023 & 0.915 & -0.112 & 0.764 \\
(5)マンション行政指導 & -0.027 & 0.785 & 0.013 & 0.596 \\
(3)不動産取引時情報提供 & -0.013 & 0.611 & 0.127 & 0.462 \\
(1)住民への情報提供 & -0.038 & -0.011 & 0.824 & 0.641 \\
(4)住民と行政話し合い & 0.032 & -0.004 & 0.813 & 0.683 \\
\hline$\alpha$ 係数 & 0.849 & 0.811 & 0.798 & - \\
\hline
\end{tabular}

次に活断層周辺の防災対策に関する意識の構成 因子を把握するため, 表 3 に示した 11 の設問項 目を用いて因子分析を行った。表 4 に分析結果 を示す。分析においては主因子法, Promax 回転
を適用した。また共通性の低い項目について 0.4 を基準として除外していった結果，「11罰則的な 税金をかけること」及び「(6)安全基準を高めるこ と」は分析過程において除外された。各因子の意 
味の解釈可能性を考慮して分析を行った結果, 3 つの因子が抽出された。表 4 より, 第 1 因子は 「建築の規制の需要」, 第 2 因子は「ソフト的対 策の需要」, 第 3 因子は「リスクコミュニケーショ ンの需要」と解釈した。

\section{3-5）各意識項目間の関連構造}

ここでは，一般的な地震リスクに関する意識と 地震防災対策に関する意識, 及び活断層周辺地域 の防災対策に関する意識の関連性を検討してい く。はじめに, 因子分析結果から得られた「建築 の規制の需要」,「ソフト的対策の需要」,「リスク コミュニケーションの需要」の各因子の構成を確 認するため, 共分散構造分析を行う。共分散構造 分析は, 構成概念間や観測変数間の因果構造を構 造方程式モデルで表現することを可能にする分析 手法である（豊田, 1998）。各項目間の因果関係 は矢印とパス係数で表現される。共分散構造分析 の結果を図 5 に示す。なお, 分析においては最 尤法を適用した。

モデルの適合度を表す指標は $\mathrm{GFI}=0.965$, $\mathrm{AGFI}=0.934, \mathrm{RMSEA}=0.063$ であり，良好で ある。図 5 より,「建築の規制の需要」,「ソフト 的対策の需要」,「リスクコミュニケーションの需 要」の各因子についてみると, 各潜在変数から観 測変数へのパス係数はいずれも 0.60 以上の值で あり，構成概念として成り立っていることが示さ れている。住民の意識においても，「II. 活断層 情報を考慮した土地利用の事例と対策の考え方」 で示した対策の枠組みと同様の分類であることが 把握された。

次にこれらの構成因子と地震リスクに関する各 意識項目, 地震防災対策の重要性に関する意識項 目を用いて全体の関連構造を共分散構造分析（最 尤法)によって分析した。分析結果を図 6 に示す。

活断層情報を考慮した防災対策に関する各潜在 変数と地震防災対策の重要性に関する意識項目間 の関係に着目すると, 因果関係として高い值を示 すのは,「被害軽減のための土地利用の推進」か らのパス係数であり，3つの潜在変数に対して統 計的に有意であった。また「リスクコミュニケー ションの需要」に対しては,「住民の防災対策」,

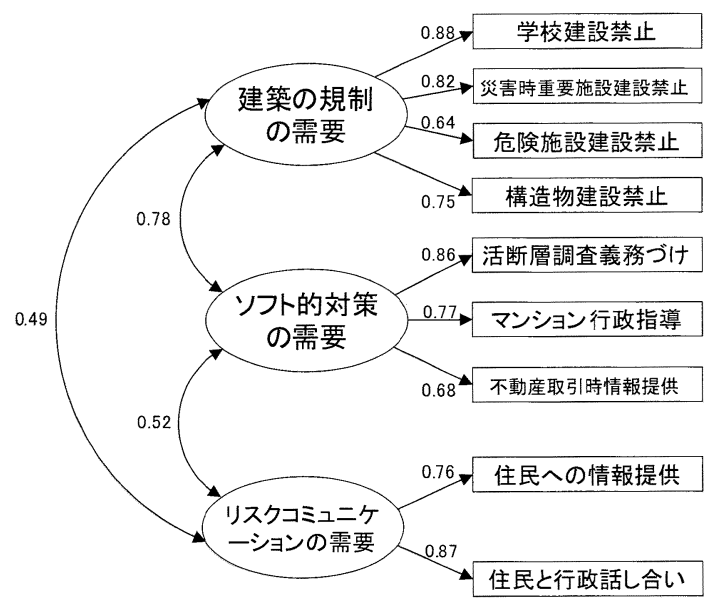

図 5 構成因子の関係.

Fig. 5 Relationship among latent variables.

「基盤施設の整備・強化」,「被害軽減のための土 地利用の推進」からのパス係数において統計的に 有意ではあったが, その他の潜在変数では,「被 害軽減のための土地利用の推進」からのパス係数 以外では有意とはならなかった。一方で地震リス クの危機意識に関する項目と地震防災対策の重要 性に関する意識項目の関係についてみると, 各パ ス係数ともに低い值であり, 統計的に有意な值と はならなかった。

\section{IV. 考察}

\section{1）活断層情報を考慮した土地利用の推進}

我が国において，活断層情報を考慮して何らか の対策を実施する根拠となる法制度は整備されて いない。しかし活断層情報を考慮して対策を検討 することは，活断層情報の精度が向上している科 学的側面とともに, 情報の透明性や活用が求めら れている社会的側面の雨面からも求められること である。

分析結果より，活断層情報を考慮した防災対策 を推進することに関して, その方法によって程度 は様々ではあるが，おおむね賛成であることが把 握された（表 3 ）。しかし実際に活断層情報を考 慮して建築の規制を実施しようとする際には, 様々な困難がつきまとうことは容易に予測される 


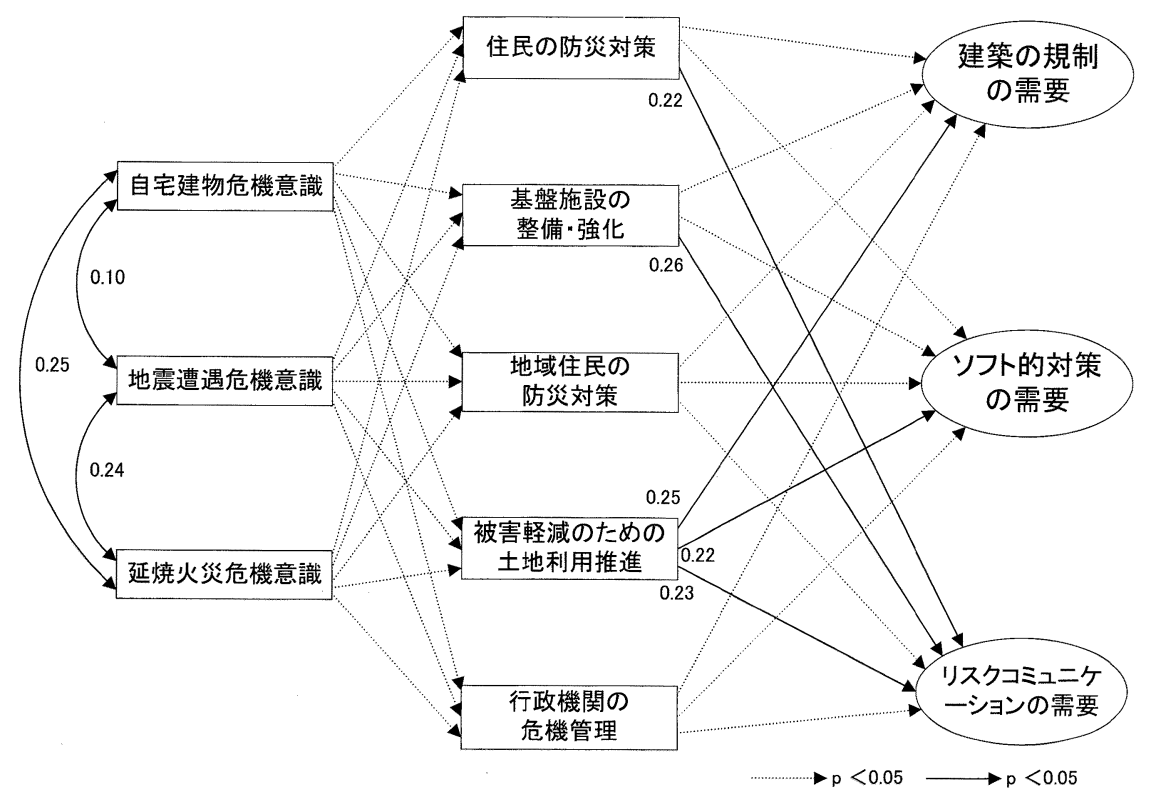

図 6 各意識項目間の関連構造.

Fig. 6 Relationship among each item.

ことである。そのため，構造物に対する規制のみ ならず，様々な方法によって危険性を低減する方 法を検討することが求められる。その方法につい て本稿では,「建築の規制」,「ソフト的対策」, 「リスクコミュニケーション」の 3 つに分けて考 えてきた。この分類については住民の意識構造に おいても同様であった（図 5)。

「建築の規制」について，すでに市街地化され た地域においてすべての建築を禁止することは現 実的ではない。しかし重要建築物や危険施設等, 特定の建築物に対しての規制を検討することは可 能であろう。表 3 に示した結果からも，危険施 設や重要な公共施設等の特定の構造物に対しての 規制には，全ての構造物に対する規制と比較し て，より意向が強い傾向にあった。また建築を規 制する方法だけでなく，「ソフト的対策」を実施 していくことも重要な方法である。その一つとし て, 新規に建設する建築行為者に対して活断層に 関する情報を提供することがあげられる。住民が その場所の危険性を知った上で居住地として選択 するかどうかは実用的にも倫理的にも重要である
とともに，その場所の危険性を認知しているかど うかは防災対策としても重要である。実際に建築 の規制, 構造性能をより高くする等何らかの対策 を講じるかは別として, 表 3 の結果からも示さ れるように，少なくとも情報を提供することは住 民としても求めていることである。

「リスクコミュニケーション」は, 重要構造物 や危険施設を地域の土地利用計画においてどのよ うに位置づけるのかを検討するためにも重要であ る。リスクコミュニケーションによって防災対策 に関する住民の理解が深まれば，活断層情報を考 慮した防災対策の需要も高まり，防災対策をより 推進できる可能性のあることが示された（図 6)。

また図 6 に示した分析結果より, 被害軽滅の ための土地利用の推進に関する意識は, 建築の規 制を需要する意識だけではなく，ソフト的対策の 需要, リスクコミュニケーションの需要の意識と も関連づけられていることが示された。災害を軽 減するための土地利用の必要性に関する意識が高 まれば，様々な対策につながることを示唆してい る。建築物の重要度と危険性に応じてどのように 
利用していくかは，地域の特性に応じて対策を検 討していくべきである。防災性能とともに地域の 様々な要素を考慮して, リスクコミュニケーショ ンに基ついて長期的な観点から計画を検討するこ とが必要である。

\section{2）防災対策を推進していく上でのリスクコ} ミュニケーションの課題

活断層情報の公開と情報提供については, 日本 国内においても地震調査研究推進本部や各自治体 によって取り組まれているところである。しかし 国内の状況についてみるとき，活断層情報は提供 されてはいるがそれらは具体的には活用されてお らず，一方的な情報提供のみに終わっていると思 われる。

分析結果から, 首都圈直下地震よりも武山断 層, 衣笠・北武断層の認知度が相対的に低いこと が示された（図 3)。地域の具体的な活断層より も首都圈直下地震という南関東地域全般を対象と している地震危険性のほうがよく知られているの は，地域からの情報よりも報道機関を通じて入っ てくる情報内容のほうが多いことに起因している と考えられる。

地域に存在する活断層等, その地域の危険特性 を住民に知らせていくことはリスクコミュニケー ションにおいて第一に求められることである。そ の上で，その危険性を自分のこととして考えられ るようにしていく工夫が求められている。表 1 に 示した相関分析結果からは, 首都圈直下地震等に 対する危機感は地震に遭遇する危険性や地域の延 焼火災の危険性としてある程度は結びつけて考え られるが，自宅建物の危険性とは意識の中であま り結びつけられて考えられていないことがわか る。各個人の意識構造においてこれらが関連づけ られるようになれば，個人レベルでの防災対策も より推進していくと考えられる。個人レベルでの 防災対策が進まない原因も, 自宅等の自分のこと に関する危機感と, それに対する首都圏直下地震 や地域の活断層等に関する危機感との関係の希薄 さに起因していると考えられる。

また危機感と防災対策の重要性に関する項目間 の関連性も弱かった（図 6)。住民の意識レベル
において，地震リスクに関する意識と対策の意向 との関連性の低いことが示された。これは，地震 の危険性を自分のこととして考えられていないこ とも一因としてあると考えられる。これらの関連 性を意識レベルにおいてもつなげられるようにす ることは，防災対策を推進するもとになるものと して, 一つの重要な課題だと考えられる。地震リ スクに関する意識と対策を推進する意識が個々人 の意識の中において関連づけられることは，個人 レベルの防災対策のみならず，地域レベルの防災 対策を推進することにもつながる。

\section{謝 辞}

本稿は文部科学省科学研究費補助金基盤研究 A（1） 「アジアに打ける住宅・都市復興と被災都市の社会・空 間変容に関する比較研究」(研究代表者：中林一樹）の 研究成果である。

\section{注}

1）リスクコミュニケーションは，個人，機関，集団 間に扮ける情報や意見の相互的な交換過程と定義さ れることが多い。リスクコミュニケーションについ ては，例えば，広瀬（2000）を参照できる。

2）西宮市の「震災に強いまちづくり条例」は 5 年の 時限付きであった。そのため現在, 「震災に強いまち づくり条例」は廃止されており, 活断層線周辺地域 の建築指導に関する項目は別の条例の一部に組み込 まれている。

3）横須賀市野比 4 丁目地区の事業については増田・ 村山（2001）に詳しい。

4) 本論に示した事例以外に，トルコに拀いても建築規 制されている事例がある（久野ほか, 2004）。

5）活断層法の成立の経緯や対策の現況に関しては, Geschwind (2001), 中田（1990）に詳しい。

6) Alquist-Priolo Special Studies Zoning Act では「特 別調查地带 (special studies zones)」と呼ばれている。

7）カリフォルニア州では災害危険区域において土地 や建物の売買が行われるとき, 売り手が買い手に対 して危険性のある土地であることを知らせる必要の あることがCalifornia Civil Code 1103 に打いて規定 されている (Official California Legislative Information H.P. : http://www.leginfo.ca.gov/calaw.html [Cited 2007/01/31])。この法律は 1998 年に制定さ れており，そこでは地震の危険性だけでなく，火災， 水害等の自然災害に対しても危険情報の提供義務の あることが記されている。

8) Resource Management Act, Resource consentに ついては以下のホームページを参照できる。

http://www.dges.tohoku.ac.jp/ murayama/NZGuideline.htm [Cited 2007/01/31]。

9）地震調查研究推進本部に扔いて, 武山断層の今後 
30 年間の地震発生確率は 6-11\%，衣笠・北武断層帯 は 0-3\%と試算されている。

\section{文献}

馬場美智子 (2003): 災害リスクマネジメント概念を導 入した土地利用規制に関する考察。地域安全学会論 文集， 5，327-334.

馬場美智子 - 増田 聡・村山良之・牧 紀男 (2004): ニュージーランドの防災型土地利用規制に関する考 察. 日本都市計画学会都市計画論文集，39-3，601606.

Geschwind, C.H. (2001): California Earthquakes. The Johns Hopkins University Press.

広瀬弘忠 $(2000)$ : リスクコミュニケーションのプロセ スと送り手の信頼性. 日本リスク研究学会編：リス ク学事典. TBS ブリタニカ, 280-281.

地震調查研究推進本部政策委員会成果を社会に活かす 部会 (2001): 政策委員会成果を社会に活かす部会報 告.

神奈川県 (2001): 平成 12 年度地震関係基礎調査交付 金事業 三浦半島断層群に関する調查成果報告書.

久野早江子・中林一樹・高見澤邦郎 (2004): トルコ・ コジャエリ地震後の自治体による既成市街地復興活 動に関する研究. 地域安全学会梗概集， 15，125128.

増田 聡・村山良之 (1998): 防災型土地利用規制の社 会的受容・実施に関わるアジェンダ形成の検討. 日 本都市計画学会学術研究論文集, 33, 829-834.

増田 聡・村山良之（2001）：地方自治体における防災 対策と都市計画. 地学雑誌， 110，980-990.

村山良之・増田 聡 (2001): 活断層上への防災型土地 利用規制の導入可能性. 季刊地理学, 53, 34-44.
中田 高 (1990): カリフォルニア州の活断層法「アル キストープリオロ特別調查地帯法 (Alquist-Priolo Special Studies Zones Act)」と地震対策. 地学雑誌, 99, 81-90.

中田 高 (1996): 都市圈活断層の危険度評価と対策. 活断層研究，15，109-111.

中田 高・隈元 崇 (2003): 活断層位置情報からみた 土地利用の問題点と「活断層法」について. 活断層 研究, 23, 13-18.

損害保険料率算定会 $(2000)$ : 地震危険に関するアンケー 卜調查（専門家編）（地震保険調査報告 32），12-14.

鈴木康弘 (2001): 活断層大地震に備える. ちくま新書. 照本清峰 (2004): 活断層周辺区域の防災対策とリスク コミュニケーション. 地理, 589, 49-53.

照本清峰 (2007): 活断層情報と地震リスク対策. 減災, 2, 116-127.

照本清峰・望月利男 (2001) : 地震情報に対する被害危 険区域住民の防災意識と対策行動及び対策需要の規 定要因に関する分析. 地域安全学会論文集， 3，233240.

照本清峰・王 雪雯 (2001): 台湾における車籠埔断層 沿線区域の建築制限の実態と課題. 日本都市計画学 会都市計画論文集，36，97-102.

照本清峰・王 雪雯・中林一樹 (2005): 台湾における 車籠埔断層沿線区域の建築制限の展開と住民の対応. 日本都市計画学会都市計画論文集，40-3，703-708. 豊田秀樹 (1998): 共分散構造分析 [入門編]. 朝倉書店. 読売新聞朝刊〔大阪本社発行版〕（2006 年 1 月 15 日）： 特集記事「活断層市民調査」.

（2007 年 2 月 2 日受付, 2007 年 7 月 2 日受理) 